\title{
Grain Yield and Yield Components of Quality Protein Maize Genotypes as Influenced by Irrigation and Plant Population in the Nigerian Savannah
}

\author{
B. M. Sani ${ }^{1}$, I. U. Abubakar ${ }^{2}$, A. M. Falaki ${ }^{2}$, H. Mani ${ }^{2} \&$ M. M. Jaliya ${ }^{1}$ \\ ${ }^{1}$ Agricultural Engineering \& Irrigation Department, National Agricultural Extension \& Research Liaison Services, \\ NAERLS, Ahmadu Bello University, Nigeria \\ ${ }^{2}$ Department of Agronomy, Faculty of Agriculture/Institute for Agricultural Research, Ahmadu Bello University, \\ Zaria, Nigeria \\ Correspondence: B. M. Sani, Agricultural Engineering \& Irrigation Department, National Agricultural Extension \\ \& Research Liaison Services, NAERLS, Ahmadu Bello University, Nigeria. Tel: 234-806-813-4944. E-mail: \\ bashirsani@yahoo.com
}

Received: January 14, 2014 Accepted: February 26, 2014 Online Published: March 15, 2014

doi:10.5539/jas.v6n4p166 URL: http://dx.doi.org/10.5539/jas.v6n4p166

\begin{abstract}
An experiment was conducted to assess the yield and yield components of QPM genotypes to plant population under irrigated conditions in a semi arid ecology of Northern Nigeria. Field trials were conducted at the Irrigation Research Station, Institute for Agricultural Research, Kadawa $\left(11^{\circ} 39^{\prime} \mathrm{N}, 08^{\circ} 20^{\prime} \mathrm{E}\right)$ and $500 \mathrm{~m}$ above sea level) during dry seasons 2007, 2008 and 2009 to study the effect of (Zea mays L.) genotypes (TZE-W Pop X 1368, EV-DT W99 STR and DMR-ESRW), four plant population (33333, 44444, 55555 and 66666 plants ha $\left.^{-1}\right)$ and three irrigation scheduling (40, 60 and 80 centibars soil moisture tension) on the growth and yield of quality protein maize. A split plot design was used with combinations of genotypes and irrigation regimes assigned to the main plot and plant population assigned to the sub-plot. The treatments were replicated three times. The study revealed that genotype EV-DT W99 STR had significantly higher weight of ears per plant, cob length, cob diameter, number of rows per cob, 100 grain weight, grain yield, shelling percentage and harvest index than the other two genotypes used in the trial. Irrigating at 40 and 60 centibars significantly increased weight of ears per plant, while delayed irrigation significantly depressed total dry matter production. Based on the results obtained in this study, it can be concluded that the use of genotype EV-DT W99 STR, at 60 centibars irrigation scheduling and population of 55,555 plants ha ${ }^{-1}$ had resulted in good agro-physiological characters of QPM at Kadawa.
\end{abstract}

Keywords: grain yield, quality protein maize (QPM), plant population, irrigation, savannah ecology

\section{Introduction}

Maize is a very important cereal crop in Nigeria ranking third among cereal crops after sorghum and millet (FAO, 2008). It is the most widely distributed cultivated crop in Nigeria with cultivation from the wet ever green forest zone to the dry ecology of the Sudan savanna (Abubakar et al., 2001). It is a major cereal crop for human nutrition and livestock feed. Despite its widespread use across the country however, maize consumed in Nigeria is mainly dent maize, which has a nutritional constraint as human food because, even though it has about $10 \%$ protein, it is deficient in three essential amino acids: lysine, tryptophan and niacin and contains on average about $2 \%$ lysine which is less than one-half of the concentration recommended by the Food and Agriculture Organization of the United Nations (Prasanna et al., 2001). The promotion and cultivation of high yielding maize hybrids/varieties, that are of good nutritional quality, and tolerant/resistant to several biotic and abiotic constraints is therefore a pre-requisite to solving food insecurity in Nigeria (Ado et al., 2009). Maize production in Nigeria is characterized by low productivity due to a variety of factors which include low plant density, poor soil management practices, unavailability of water, pests and diseases and many others. However, low yield due to sub-optimal population density and poor water management practices are some of the problems causing low productivity. In farmers' fields, maize plant density varies greatly e.g. 15,000 - 51,000 plants/ha (Mutsaers et al., 1995), but are below the optimum density (66,000 plants/ha) recommended for high yields (Kang \& Wilson, 1981). Maize is the agronomic grass species that is most sensitive to variations in plant population. For each production system, there is a 
population that maximizes grain yield. Irrigated agriculture is assumed to be more productive due to the control exerted on moisture supply. As this resource is not limiting, it can be assumed that yield from irrigated agriculture would be higher than from rainfed. The importance of plant population as a factor determining growth and yield of early maize cultivars has been established (Gretzmacher, 1979; Zarogiannis, 1979; Bavec, 1988). As a result of this facts, it can be assumed that areas with irrigation facilities should be able to support the cultivation of quality protein maize. This will provide a dual advantage of being a source of improved nutrition and fodder for livestock at the peak of the 'hunger' period. This study was therefore undertaken to investigate the response of yield characters of QPM genotypes to irrigation and plant population.

\section{Materials and Methods}

\subsection{Experimental Site}

The study was conducted under irrigation during dry seasons of 2007, 2008 and 2009 at the Kadawa Irrigation Research Sub-Station of the Institute for Agricultural Research, Ahmadu Bello University, Zaria. The site is located in the Sudan Savanna ecological zone of Nigeria ( $11^{\circ} 39^{\prime} \mathrm{N}, 08^{\circ} 20^{\prime} \mathrm{E}$ and $500 \mathrm{~m}$ above sea level). The area has a cool dry season that has the north-eastern winds, which are cool and contain dust blown from the Sahara Desert. The minimum temperature ranges between $11^{\circ} \mathrm{C}-18^{\circ} \mathrm{C}$ in the cool months (November to March) with maximum temperatures of $25^{\circ} \mathrm{C}-40^{\circ} \mathrm{C}$ in the warmer months (April to October) which is ideal for cultivation of wide variety of crops in the dry season. The soils are, in general, moderately deep and well drained with sandy loam textured surface and sandy clay loam textured subsoil.

\subsection{Treatments and Experimental Design}

The treatments consisted of three QPM genotypes (TZE-W Pop x 1368, EV DT-W 99 STR, and DMR-ESRW) three irrigation scheduling regimes (40,60 and 80 centibars soil moisture tension) and four plant population $\left(33333,44444,55555\right.$ and 66666 plants h $\left.^{-1}\right)$. The experiment was laid out in a split plot design in which a factorial combination of genotype and irrigation scheduling were assigned to the main plot and plant population density was assigned to the sub-plots and replicated three times. The experimental site was ploughed, harrowed to a good tilth and ridged. Ridges were marked out into plot sizes, and furrows served as channels for irrigation purposes.

\subsection{Cultural Practices}

The seeds of three early maturing QPM genotypes (TZE-W Pop x 1368, EV DT-W 99 STR, and DMR-ESRW) were obtained from the Institute for Agricultural Research, Samaru. The seeds were treated with Apron star (Thiametoxam + metalaxyl-N and difenoconazole) at the rate of 1 sachet of $10 \mathrm{~g}$ per $2 \mathrm{~kg}$ of seed. The seeds were sown by hand at the rate of 2 seeds per hole and were later thinned to one plant per stand at 2 weeks after sowing (WAS). Planting was done on February 14, 2007, February 21, 2008 and February 17, 2009 respectively. The inter row spacing was $75 \mathrm{~cm}$ whereas the intra row spacing used was $40 \mathrm{~cm}(33,333$ plants $/ \mathrm{ha}) 30 \mathrm{~cm}(44,444$ plants/ha) $24 \mathrm{~cm}(55,555$ plants/ha) and $20 \mathrm{~cm}(66,666$ plants/ha) respectively in order to achieve the desired plant population.

\subsection{Description of Genotypes Used}

The QPM genotypes used for the study were TZE-W Pop x 1368 (Open pollinated, white seeded, early maturing, tolerant to Striga hermonthica,), EV DT-W 99 STR (Open pollinated, white seeded, early maturing, tolerant to Striga hermonthica), and DMR-ESRW (Open pollinated, white seeded, early maturing, tolerant to Striga hermonthica and downy mildew). Furrow method of irrigation was used in supplying water to the crop. Irrigation treatment was imposed beginning from 4 WAS.

\subsection{Irrigation}

The irrigation was done at 40, 60 and 80 centibars soil moisture tension. A tensiometer was installed at each main plot for the purpose of taking the reading.

\subsection{Weed Control}

Weeds were controlled with the use of a pre-emergence herbicide; a mixture of metalachlor + atrazine (2:1) was applied at the rate of $1.5 \mathrm{~kg}$ a.i./ha (4 litres $/$ ha) supplemented by hoe weeding at $6 \mathrm{WAS}$ in the experimental plots and around the field.

\subsection{Fertilizer Application}

Fertilizer was applied at the rate of $120 \mathrm{~kg} \mathrm{~N}, 26 \mathrm{~kg}$ P and $50 \mathrm{~kg} \mathrm{~K}$ per hectare. Half the $\mathrm{N}$ and all $\mathrm{P}$ and $\mathrm{K}$ were applied at two weeks after sowing by side placement $8-10 \mathrm{~cm}$ away from the base of the plant stands. At 6 WAS, 
the other half of $\mathrm{N}$ was applied by side placement $8-10 \mathrm{~cm}$ away from the base of the plant stands and followed by irrigation.

\subsection{Harvesting}

Harvesting was carried out when the cobs have dried enough and the leaf sheaths have turned brown in colour.

\subsection{Statistical Analysis}

The data collected were statistically analysed using the SAS software.

\section{Results}

\subsection{Genotype}

The effect of genotype, on grain yield and yield components over three years is shown in Table 1. The results indicate that genotype significantly influenced all parameters (weight of ears per plant, cob length, cob diameter, number of rows per cob, 100 grain weight, grain yield, shelling percentage and harvest index) in the same pattern with genotype EV-DT W99 STR QPM having significantly higher figures than the other two genotypes which were statistically similar.

Table 1. Effects of genotype, irrigation scheduling and plant population on number of ears per plant, cob length, cob diameter and number of rows of grains per cob of QPM genotypes during 2007-2009 dry season at Kadawa

\begin{tabular}{|c|c|c|c|c|c|c|c|c|}
\hline Treatment & $\begin{array}{l}\text { Weight of } \\
\text { ears/plant }(\mathrm{g})\end{array}$ & $\begin{array}{l}\text { Cob length } \\
(\mathrm{cm})\end{array}$ & $\begin{array}{l}\text { Cob diameter } \\
(\mathrm{cm})\end{array}$ & $\begin{array}{l}\text { No. } \\
\text { rows/cob }\end{array}$ & $\begin{array}{l}100 \text { grain } \\
\text { weight }(\mathrm{kg})\end{array}$ & $\begin{array}{l}\text { Grain yield } \\
(\mathrm{kg})\end{array}$ & $\begin{array}{l}\text { Shelling } \\
\text { Percentage }\end{array}$ & $\begin{array}{l}\text { Harvest } \\
\text { index }\end{array}$ \\
\hline \multicolumn{9}{|l|}{ Genotype } \\
\hline $\begin{array}{l}\text { TZE-W Pop X } 1368 \\
\text { QPM }\end{array}$ & $112.62 b$ & $15.38 \mathrm{~b}$ & $3.74 b$ & $19.49 \mathrm{~b}$ & $25.48 b$ & $1995 b$ & $0.48 \mathrm{~b}$ & $0.49 a$ \\
\hline $\begin{array}{l}\text { EV-DT W99 STR } \\
\text { QPM }\end{array}$ & $148.81 \mathrm{a}$ & $17.05 \mathrm{a}$ & $4.56 \mathrm{a}$ & $23.21 \mathrm{a}$ & $30.33 a$ & $3215 a$ & $0.66 \mathrm{a}$ & $0.51 \mathrm{a}$ \\
\hline DMR-ESRW QPM & $114.76 \mathrm{~b}$ & $15.12 b$ & $3.74 b$ & $18.84 b$ & $25.44 \mathrm{~b}$ & $2034 b$ & $0.44 \mathrm{~b}$ & $0.44 \mathrm{~b}$ \\
\hline $\mathrm{SE}( \pm)$ & 3.11 & 0.20 & 0.05 & 0.73 & 0.27 & 73.33 & 0.03 & 0.02 \\
\hline \multicolumn{9}{|l|}{$\begin{array}{l}\text { Irrigation } \\
\text { scheduling (I) }\end{array}$} \\
\hline 40 centibars & $134.60 \mathrm{a}$ & 15.92 & 4.07 & $19.80 \mathrm{~b}$ & 27.27 & 2556 & 0.48 & $0.51 \mathrm{a}$ \\
\hline 60 centibars & $118.64 b$ & 16.04 & 3.96 & $22.37 \mathrm{a}$ & 27.33 & 2344 & 0.44 & $0.43 \mathrm{ab}$ \\
\hline 80 centibars & $131.94 a$ & 15.58 & 4.01 & $19.37 \mathrm{~b}$ & 26.66 & 2343 & 0.43 & $0.39 \mathrm{~b}$ \\
\hline $\mathrm{SE}( \pm)$ & 3.11 & 0.20 & 0.05 & 0.73 & 0.27 & 73.33 & 0.03 & 0.02 \\
\hline \multicolumn{9}{|l|}{ Plant population (P) } \\
\hline 33,333 plants ha ${ }^{-1}$ & $142.40 \mathrm{a}$ & 14.89 & 4.01 & 20.42 & $27.71 \mathrm{a}$ & $2371 b$ & 0.60 & 0.45 \\
\hline 44,444 plants ha ${ }^{-1}$ & $133.78 \mathrm{ab}$ & 16.22 & 3.95 & 20.65 & $27.82 \mathrm{a}$ & $2441 b$ & 0.61 & 0.41 \\
\hline 55,555 plants ha ${ }^{-1}$ & $131.84 \mathrm{bc}$ & 15.91 & 4.08 & 19.87 & $26.34 b$ & $2570 \mathrm{ab}$ & 0.65 & 0.48 \\
\hline 66,666 plants ha ${ }^{-1}$ & $121.25 \mathrm{c}$ & 16.38 & 4.01 & 21.14 & $26.47 \mathrm{~b}$ & $2806 \mathrm{a}$ & 0.62 & 0.48 \\
\hline $\mathrm{SE}( \pm)$ & 3.59 & 0.23 & 0.05 & 0.84 & 0.32 & 84.67 & 0.05 & 0.03 \\
\hline \multicolumn{9}{|l|}{ Interaction } \\
\hline Gx I & $*$ & $*$ & $*$ & NS & $*$ & $*$ & $*$ & $* *$ \\
\hline G x P & NS & NS & NS & NS & $*$ & $*$ & NS & NS \\
\hline $\mathrm{I} \times \mathrm{P}$ & $*$ & $*$ & $*$ & NS & $*$ & $*$ & NS & NS \\
\hline
\end{tabular}

\subsection{Irrigation Scheduling}

Irrigation scheduling had a significant influence only on weight of ears per plant, number of rows of grains per cob and harvest index. Irrigating at 40 and 80 centibars gave statistically similar weight of ears per plant and were 
significantly heavier than irrigating at 60 centibars. Irrigating at 60 centibars resulted in significantly higher numbers of rows per cob than irrigating at 40 and 89 centibars respectively. Harvest index was significantly influenced by irrigation scheduling where irrigating at 40 and 60 centibars resulted in significantly higher harvest index than irrigating at 80 centibars. There was however no significant difference in harvest index when irrigating at 60 and 80 centibars.

\subsection{Plant Population}

Plant population had a significant effect on weight of ears per plant, 100 grain weight and grain yield, while it did not significantly affect cob length, cob diameter, number of rows of grains per cob, shelling percentage and harvest index. Increasing plant population from 33,333 plants ha ${ }^{-1}$ to 66,666 plants ha ${ }^{-1}$ significantly decreased weight of ears per plant. There was no significant difference in weight of ears per plant between 55,555 and 66,666 plants $\mathrm{ha}^{-1}$, and also between 44,444 and 55,555 plants ha ${ }^{-1}$. Similarly, increasing plant population from the lowest to the highest resulted in significantly lower 100 grain weight. Plant population of 33,333 and 44,444 plants ha ${ }^{-1}$ recorded significantly higher 100 grain weight than plant population of 55,555 and 66,666 plants ha ${ }^{-1}$ respectively. Grain yield was significantly influenced by variations in plant population. Increasing plant population from 33,333 plants $\mathrm{ha}^{-1}$ to 66,666 plants ha ${ }^{-1}$ resulted in significantly higher grain yield. The results indicate that plant population of 55,555 and 66,666 plants $\mathrm{ha}^{-1}$ had significantly higher grain yield than plant population of 33,333 plants ha ${ }^{-1}$. However, 55,555 and 44,444 plants ha ${ }^{-1}$ had statistically similar grain yield.

\section{Discussion}

\subsection{Response to Genotype}

Quality protein maize genotypes can exhibit either similarities or differences in growth and development. The variation in growth could be due to genetic or environmental factors such as temperature, day length and light intensity, soil factors, cultural manipulation such as plant population, fertility and moisture supply. The yield potential of any genotype is related to its genetic constitution, which specifies the upper limit of yield or the degree to which any yield component can develop under ideal conditions. Genotypic difference had a significant effect on the performance of the genotypes. Genotype EV-DT W99 STR QPM exhibited superior growth and yield performance in most of the parameters assessed than the other two genotypes (TZE-W Pop X 1368 QPM and DMR-ESRW QPM). This could be due to some inherent genetic and physiological differences that exist between the varieties. Growth characters are genetically controlled and to some extent influenced by the environment. Genotype EV-DT W99 STR QPM had significantly higher weight of ears per plot, cob length, cob diameter, number of rows per cob, 100 grain weight, grain yield per hectare, harvest index, shelling percentage and total aerial biomass than the other two genotypes. This trend was also observed by Badu-Apraku and Fontem-Lum (2010) with these same genotypes in trials across Nigeria. Genotype TZE-W Pop X 1368 QPM however, exhibited shorter days to 50\% tasseling and silking, higher harvest index and total aerial biomass as genotype EV-DT W99 STR QPM. Genotype DMR-ESRW QPM did not exhibit any superior traits over the other two genotypes. Many workers have reported growth and yield differentials among different maize varieties and genotypes (Hamidu, 1999; Bello, 2001; Ogunbodede et al., 2001; Mani, 2004; Abdulai et al., 2007; Abdelmula \& Sabiel, 2007; Sharifi \& Taghizadeh, 2009; Badu-Apraku \& Fontem-Lum, 2010).

\subsection{Response to Irrigation}

Varying irrigation scheduling did not significantly influence yield parameters except number of ears per plant, number of rows per cob, harvest index, shelling percentage and total aerial biomass which were significantly affected by irrigating at 0.4 and 0.6 centibars respectively. All other yield parameters including grain yield per hectare were not significantly affected by varying irrigation scheduling regime. The significance of this result may be that yield contributing factors are more genetically controlled than environmental. This conforms with results obtained by Abdelmulla and Sabiel (2007) who found non significant effect of subjecting maize genotypes to drought stress in Sudan, but different from that of Hussaini 2000, who observed significant response to increased irrigation frequency on maize at Kadawa. This result can be interpreted on the basis of the fact that at mild water stress, there is the possibility of increased root volume which might have led to more surface area for water absorption (Mayaki et al., 1976; Shaw, 1978). Furthermore, the texture of the soil of the study area (medium texture) may have been able to withstand or withhold soil moisture up to 0.8 centibars and might have thus met the minimum requirements for growth of maize. Similarly Yang et al. (1993) working with tensiometers on maize found significant effect of scheduling irrigation with tensiometers on maize. The response of genotypes to stress differs according to their genetic structure and adaptability. In this particular study, one of the genotypes (EV-DT W99 STR QPM) has an inherent genetic capability to withstand drought. Wenzel (1999) reported that some genotypes yielded more under moisture stress than under near ideal moisture conditions. Other reasons for the non 
significant response to varying irrigation regimes by the genotypes could be the fact that Kadawa irrigation site has appreciable high water table $(65-80 \mathrm{~cm}$ post rainy season; 100 to110 cm, pre-wet season, Malgwi et al., 2009) and that response of the crop to irrigation depends largely on the soil types, climate and water table of the cropped area. Maize has an average rooting depth of about $1.2 \mathrm{~m}$ and Hussaini et al. (2008) estimated the effective rooting depth of maize at Kadawa to be $75 \mathrm{~cm}$. Therefore, at later stages of growth (which coincides with reproductive phase), the roots are well developed and hence can extend to lower depths to get moisture thereby negating any stress imposed by way of irrigation scheduling. Similar response to soil water deficit has been reported by Yang et al. (1993) working with maize in Taiwan.

\subsection{Response to Population}

Yield components studied responded significantly to variations in plant population. Weight of ears per plant was significantly affected by increasing plant population. The results showed that increasing plant population beyond 44,444 plants $\mathrm{ha}^{-1}$ significantly decreased weight of ears per plant. This may be attributed to the heavier cobs produced by the lower population treatment. Cob length was also significantly affected by plant population. The results indicated that increasing plant population resulted in longer cob length. This may be due to the longer vegetative growth of the more dense population which might have resulted in longer cobs. This is in consonance with reports by Kamel et al. (1983) and Shahid Ibni Zamir et al. (1999) and in contrast to what some researchers have reported that increasing plant population decreases cob length (Zhang et al., 2006; Sharifi et al., 2009). Increasing plant population resulted in significantly lower 100 grain weight. This may be attributed to less assimilate partitioning under the higher population treatments which resulted in lower individual weights of grains. The lower population treatments will receive more assimilates because of the reduced number of plants competing for such assimilates and hence will have a much heavier weight. This has been reported by Ologunde (1974), Esechie (1992). Grain yield per hectare was significantly affected by variations in plant population density. The results indicated that increasing plant population significantly increased grain yield beyond the 44,444 plants ha $^{-1}$ treatment. However, it was observed that the 55,555 plants ha $^{-1}$ treatment had grain yield at par with the 66,666 plants $\mathrm{ha}^{-1}$ treatment. Similarly, the results showed that the 33,333 and 44,444 plants ha ${ }^{-1}$ treatments had similar values of grain yield per hectare. This may be explained on the basis of the heavier 100-seed weight exhibited by the 33,333 plants ha ${ }^{-1}$ treatment relative to the 44,444 plants ha ${ }^{-1}$ treatment. Many studies have indicated that increasing plant population resulted in increased grain yield up to a maximum before declining. In this study, the highest grain yield was obtained at 55,555 plants ha ${ }^{-1}$, this was however statistically similar to 66,666 plants/ha. The reason for the significantly higher yield at the higher population treatments as compared with the low population treatments might be due to large number of plants per unit area which compensated the effects of decrease in other yield components like grain weight and grains per ear. These components, though decreased on per se basis, yet yield actually increased on per unit area basis. The results also indicate that 33,333, and 55,555 plants ha ${ }^{-1}$ treatments had the highest harvest index, while 44,444, 55,555 had the highest shelling percentage and $33,333,55,555$ and 66,666 plants ha ${ }^{-1}$ treatments had the highest total aerial biomass. Similar results have been reported by Hamidu (1999), Bello (2001), Sani (2004) and Mani et al. (2007) in similar environments and Ologunde (1974), Tollenaar (1992), Sangoi (2001), Xue et al. (2002), Zhang et al. (2006), and Sharifi et al. (2009), in other environments.

\section{Conclusion}

Growing quality protein maize genotype EV-DT W99 STR, at 60 centibars irrigation scheduling and 55,555 plants $\mathrm{ha}^{-1}$ had resulted in good yield components and grain yield at Kadawa and is thus recommended for similar ecologies.

\section{Refernces}

Abdelmula, A. A., \& Sabiel, S. A. I. (2007). Genotypic and differential response of growth and yield of some maize (Zea may L.) genotypes to drought stress. In proceedings of the 'Conference on International Agricultural Research for Development'. University of Kassel-Witzenhausen and University of Gottingen, Germany. October 9-11, 2007.

Abdulai, M. S., Sallah, P. Y. K., \& Safo-Kantanka, O. (2007). Maize grain yield stability analysis in full season lowland maize. International Journal of Agriculture \& Biology, 9(1), 41-45.

Abubakar, S. S., Onyibe, J. E., Daudu, C. K., Ahmed, J., \& Gbadegeshin, R. A. (2000). Expected role of extension in the promotion of quality protein maize. Maize for Better Nutrition, 108.

Ado, S. G., Ibikunle, O. A., Olakojo, S. A., Olaoye, G., Ogunbodede, B. A., Ajayi, S. A., ... Ogungbile, A. O. (2009). Nomination of new Open pollinated and hybrid varieties of maize with tolerance/ resistance to 
stresses for release in Nigeria. IITA Maize Improvement Programme, International Institute of Tropical Agriculture, IITA, Ibadan Nigeria.

Badu-Apraku, B., \& Fontem-Lum, A. (2010). Grain yield response of normal and quality protein maize cultivars in stress and non stress environments. Agron J., 102, 381-394. http://dx.doi.org/10.2134/agronj2009.0229

Bavec, F. (1988). Genotipske karakteristike i prinos hibrida kukuruza u zavinosti od gustine sklopa u uslovina Podravlja (Slovenija). Savremena poljoprivreda, 36, 476-481

Bello, I. (2001). Effect of plant population and sowing date on the growth, yield and yield components of Quality Protein Maize (Zea mays L.) varieties in Samaru. Unpublished M.Sc Thesis, Department of Agronomy, Ahmadu Bello University, Zaria, Nigeria.

Esechie, H. A. (1992). Effect of plant population on growth and yield of irrigated maize in Batinah West region of Oman. Journal of Agricultural Science, 119(2), 165-169. http://dx.doi.org/10.1017/S0021859600014076

Ethan, S., Bababe; B., Olaniyan, G. O., \& Misari, S. M. (1998). Irrigation water management in lowland rice crop production at Badeggi irrigation scheme. In: Irrigation in Sustainable Agriculture. Proceedings of the $12^{\text {th }}$ National Irrigation and Drainage Seminar (A. A. Ramalan (Ed.), pp. 168-177). Institute for Agricultural Research (IAR), Samaru.

Falaki, A. M., \& Miko, S. (1999). Irrigated maize production prospects and problems. National conference on sustainable maize production in Nigeria IAR/ABU, Samaru Zaria, July 22-24, 1999.

FAO. (2008). Food and Agriculture Organization Statistics, FAOSTAT. Retrieved from www.fao.org/faostat

Gretzmacher, R. (1979). Die Beeinflussung des morphologischen Entragsaufbaues und der Extragsleitung durch den Standraum bei Kornermais. Die Bodenkultur, 30, 256-280.

Hamidu, H. A. (1999). Performance of quality protein maize (QPM) at varying levels of NPK fertilizer and plant density in savanna zones of Nigeria. Unpublished M.Sc Thesis, Department of Agronomy, Ahmadu Bello University, Zaria, Nigeria.

Hussaini, M. A. (2000). Studies on irrigation scheduling, nitrogen and phosphorus fertilization of dry season maize (Zea mays L.) at Kadawa, Nigeria. Unpublished Ph.D Thesis, Department of Agronomy, Ahmadu Bello University, Zaria, Nigeria: 286.

Hussaini, M. A., Ogunlela, V. B., Ramalan, A. A., \& Falaki, A. M. (2008). Mineral composition of dry season maize (Zea mays L.) in response to varying levels of nitrogen, phosphorus and irrigation at Kadawa, Nigeria. World Journal of Agric. Sciences, 4(6), 775-780.

Kamel, M. S., Raouf, A., Mahmood, M. S., \& Amer, S. (1983). The effect of plant population on local 'Roumi' maize grain yield when grown under irrigation. Ann. Agri. Sci., 19, 79-83

Kang, B. T., \& Wilson, G. F. (1981). Effect of maize plant population and nitrogen application on maize cassava intercrop. In E. R. Terry, K. A. Oduro, \& F. Caveness (Eds.), Tropical Root Crops Research Strategies for the 1980s (pp. 129-133). Ottawa, Canada: IDRC.

Malgwi, W. B., Yaro, D. T., \& Abu, S. T. (2009). Survey of seasonal variation of water table and salinity at Kadawa Irrigation Scheme. In Report of 2009 National Irrigation Cropping Scheme Meeting (pp. 44-49). National Programme for Food Security and Institute for Agricultural Research, Ahmadu Bello University, Zaria. May 11-14, 2009.

Mani, H. (2004). Growth and yield performance of two popcorn (Zea mays everta) varieties to rate of NPK fertilizer under different irrigation interval. Unpublished Ph.D Thesis, Department of Agronomy, Ahmadu Bello University, Zaria, Nigeria.

Mani, H., Ado, S. G., Dadari, S. A., Ahmed, A., \& Kura, H. N. (2007). The effects of irrigation interval, method of irrigation and plant density on performance of sweet corn (Zea mays saccharata sturt) at Kadawa. In Proceeding of the $13^{\text {th }}$ National Irrigation and Drainage Seminar (pp. 95-99.)

Mayaki, W. C., Stone, L. R., \& Teane, F. D. (1976). Irrigated and non irrigated soybean, corn and grain sorghum $\begin{array}{lllll}\text { root } \quad \text { systems. } & \text { Agronomy } & \text { 5ournal, } & \text { 68, } & \end{array}$ http://dx.doi.org/10.2134/agronj1976.00021962006800030028x

Mutsaers, H. J. W., Adekunle, A. A., Walker, P., \& Palada, M. C. (1995). The maize and cassava production system in Southwestern Nigeria and the effect of improved technology. IITA monograph 18, IITA, Ibadan, Nigeria 
Ogunbodede, B. A., Ajibade, S. R., \& Olakojo, S. A. (2001). Grain yield stability of new maize varieties in Nigeria. African Crop Sc. J., 9(4), 685-691.

Ologunde, M. S. (1974). Effects of nitrogen and population on yield of maize (Zea mays L.). M.Sc. Thesis, University of Missouri Columbia 175.

Prasanna, B. M., Vassal, S. K., Kassahun, B., \& Singh, N. M. (2001). Quality protein maize. Current Science, 81, (25).

Sangoi, L. (2001). Understanding plant density effect on maize growth and development: An important issue to maximize grain yield. Ciencia Rural, 31, 159-168. http://dx.doi.org/10.1590/S0103-84782001000100027

Sani, B. M. (2004). Irrigation and plant density effects on growth and yield of early maize at Samaru, Northern Nigeria. Unpublished M.Sc Thesis, Department of Soil Science, Ahmadu Bello University, Zaria, Nigeria

Shahid Ibni Zamir, M., Maqsood, M., Saifi, M. A., \& Yousaf, N. (1999). Effect of plant spacing on yield and yield components of maize. Int.J. Agric. Biol., 1(3), 152-153.

Sharifi, R. S., \& Taghizadeh, R. (2009). Response of maize (Zea mays L.) cultivars to different levels of nitrogen fertilizer. Journal of Food, Agriculture and Environment, 7(3\&4), 518-521.

Sharifi, R. S., Sedghi, M., \& Gholipouri, A. (2009). Effect of population density on yield and yield attributes of maize hybrids. Research Journal of Biological Sciences, 4(4), 375-379

Shaw, R. H. (1978). Calculation of soil moisture and stress conditions in 1976 and 1977. Iowa State Journal of Research, 53, 119-127

Tollenaar, M. (1992). Is low plant density a stress in maize? Maydica, 22, 49-75.

Wenzel, W. G. (1999). Effect of moisture stress on sorghum yield and its components. South African Journal of Plant and Soil, 16(3), 153-157. http://dx.doi.org/10.1080/02571862.1999.10635002

Xue, J., Liang, Z., Ma, G., Lu, H., \& Ren, J. (2002). Population physiological indices on density-tolerance of maize in different plant type. Ying Yong Sheng Tai Xue Bao, 17(4), 657-662.

Yang, C. M., Ming-Jen, F., \&Wei-Min, H. (1993). Growth and yield response of maize (Zea mays L.) to soil water deficits. Jour. Agric. Res. China, 42(2), 173-186.

Zarogiannis, V. (1979). Beregnung und Standraum bei mais (Zea mays L.). Die Bodenkultur, 30, 281-303

Zhang, J. S., Dong, K., Wang, C., Hu, K., \& Liu, P. (2006). Effects of shading on the growth, development and grain yield of summer maize. Ying Yong Sheng Tai Xue Bao, 17(4), 657-662.

\section{Copyrights}

Copyright for this article is retained by the author(s), with first publication rights granted to the journal.

This is an open-access article distributed under the terms and conditions of the Creative Commons Attribution license (http://creativecommons.org/licenses/by/3.0/). 